Dinamika Sosial Budaya, Vol 22, No. 1, Juni 2020, pp 29-37

p-ISSN: 1410-9859\& e-ISSN: 2580-8524

http://journals.usm.ac.id/index.php/jdsb

\title{
ANALISIS SEMIOTIKA BUSANA ADAT BAGI PEREMPUAN DI PULAU BURU
}

\author{
M Chairul Basrun Umanailo \\ Fakultas Pertanian dan Kehutanan, Universitas Iqra Buru \\ chairulbasrun@gmail.com
}

\begin{abstract}
Abstrak
Pakaian adat menjadi bagian penting dalam setiap ritual dan kegiatan adat bagi masyarakat di Pulau Buru, fungsi pakaian tradisional selain pelindung tubuh juga menjadi simbol identitas yang melekat pada pakaian tersebut. Penelitian ini adalah penelitian kualitatif yang bertujuan mendeskripsikan busana adat untuk masyarakat. Lokasi penelitian berfokus pada tiga desa yaitu desa Kayeli, Desa Kubalahin dan Desa Wasi dengan pertimbangan penggunaan pakaian tradisional yang lebih sering ditemukan dibandingkan dengan desa-desa lain di Pulau Buru. Jumlah informan yang diwawancarai oleh 25 orang, yang terdiri dari tokoh adat, tokoh masyarakat, tokoh lembaga adat dan aparat desa serta masyarakat setempat yang bertempat tinggal di lokasi penelitian.Hasil penelitian menunjukkan bahwa pakaian adat di ketiga lokasi memiliki beberapa kesamaan dalam penggunaan serta perbedaan dalam penempatan busana adat. Penduduk desa Kayeli dan Wasi menggunakan pakaian tradisional untuk kegiatan menerima tamu dan kegiatan tradisional, sementara masyarakat Kubalahin menggunakan pakaian tradisional untuk kegiatan ritual. Bagi masyarakat desa pakaian adat Kayeli memiliki nilai sakral yang harus dipatuhi oleh semua orang yang menggunakannya, juga di desa Wasi dan Kubalahin, mereka menganggap bahwa identitas dalam pakaian adat harus dipertahankan dengan tidak sembarangan menggunakan atau menempatkan pakaian adat dalam kehidupan sehari-hari.
\end{abstract}

\begin{abstract}
Traditional clothing is an important part of every ritual and customary activity for people on Buru Island, the function of traditional clothing in addition to body armor is also a symbol of identity attached to the clothing. This research is a qualitative research aimed at describing traditional clothing for the community. The research location considers three villages namely Kayeli Village, Kubalahin Village and Wasi Village by considering the use of traditional clothing which is more often found compared to other villages on Buru Island. The number of informants interviewed by 25 people, consisting of traditional leaders, community leaders, traditional institution leaders and village officials as well as local communities who reside at the study site. custom clothing placement. The villagers of Kayeli and Wasi use traditional clothing for activities to receive guests and traditional activities, while the Kubalahin people use traditional clothing for ritual activities. For the people of Kayeli, the traditional clothing village has a sacred value that must be obeyed by all those who use it. Also in the villages of Wasi and Kubalahin, they consider that copyright in traditional clothing must not be arbitrarily used or used traditional clothing in everyday life.
\end{abstract}

Keywords: Fashion; custom; female; buru island 
Dinamika Sosial Budaya, Vol 22, No. 1, Juni 2020, pp 29-37

p-ISSN: 1410-9859\& e-ISSN: 2580-8524

http://journals.usm.ac.id/index.php/jdsb

\section{PENDAHULUAN}

Kehadiran semiotika memberikan tawaran peluang untuk melihat sesuatu dari sudut yang lain. Dasar pijakan untuk memahami semiotik adalah "tanda". Tanda ada dimana-mana; segala sesuatu dapat menjadi tanda, dan dengan sarana tanda kita dapat berpikir dan tanpa tanda tidak dapat berkomunikasi. Basis dari seluruh komunikasi adalah tanda; melalui perantara tanda-tanda manusia dapat melakukan komunikasi dengan sesamanya. Salah satu media komunikasi yang unik dan menarik adalah seni yang terkandung dalam pakaian adat perempuan di Pulau Buru. Seperti objek atau artefak umum lainnya, kita menafsirkan pakaian sebagai tanda yang mewakili hal-hal seperti kepribadian, status sosial, dan karakter keseluruhan si pemakai. Sekali lagi, metode dasar pakar semiotika yaitu menanyakan apa, bagaimana, dan mengapa sesuatu memiliki makna yang kini dimilikinya, berlaku pula pada pakaian. Pakaian adat perempuan di Pulau Buru merupakan suatu tanda kebudayaan yang sangat bernilai dan dimiliki oleh sebagian besar suku asli di Pulau Buru serta memiliki arti dan makna tersendiri bagi suku tersebut (Eirumkuy Balai Pelestarian Nilai Budaya Ambon Jln IrMPutuhena Wailela Rumahtiga Ambon, 2013). Secara umum orang berpendapat bahwa kesenian adalah hasil ekspresi jiwa manusia akan keindahan. Sebenarnya tidak semua hasil karya seni dapat dinyatakan demikian, karena ada karya seni yang lebih mengutamakan pesan budaya dari masyarakat yang bersangkutan (Kodariah dan Gugun Gunardi, 2015). Masyarakat suku buru bermaksud menginterprestasikan permasalahan dalam kehidupan sosial, mencapai suatu kebutuhan bersama, seperti kemuliaan, persatuan, dan saling menghargai satu sama yang lainnya Kesenian merupakan ekspresi keindahan yang memiliki pesan budaya dalam berbagai macam bentuk, Seperti seni tari, seni patung, seni instrumental, dan seni dalam pakaian. Kajian semiotika yang terdapat dalam pakaian adat perempuan di Pulau Buru tentunya akan sangat menjelaskan lebih detail mengenai arti dan makna itu sendiri. Peneliti mencoba untuk mengetahui lebih dalam dengan mengkajinya melalui teori semiotik, dimana peneliti akan mengkaji "tanda" sebagai kajian semiotikanya.

Kajian ini bertujuan untuk untuk menganalisis sebuah tanda yaitu busana adat bagi perempuan di Pulau Buru melalui studi semiotik. Penelitian ini berusaha membuka makna dari tanda-tanda yang digunakan sekaligus menyingkapkan pesan yang secara tersembunyi terkandung di dalam busana adat tersebut. Penelitian ini adalah penelitian yang menggunakan metode penelitian semiotik yaitu penelitian yang berusaha menginterpretasikan atau mengartikan suatu tanda atau objek melalui kajian semiotik. Dengan menggunakan metode Pierce sebagai analisis utama, data-data yang disajikan menggunakan data primer dan sekunder melalui wawancara, artikel mengenai busana adat bagi perempuan di Pulau Buru, bukubuku dan internet, kemudian teknik analisis data yang digunakan pada penelitian ini adalah model segitiga triadik oleh C.S Pierce.

Jalung (2015) dalam penelitiannya tentang analisis semiotika pakaian adat Dayak Bahau menunjukan bahwa pakaian sebagai alat komunikasi budaya suku Dayak Bahau hingga saat ini masih terus mengalami perkembangan dan sedikit demi sedikit mengalami pergeseran makna budaya (Nugrahenny, 2018). Dimana kini pengguna pakaian bukanlah lagi seorang yang berasal dari suku Dayak Bahau saja, melainkan di luar dari suku tersebut. Bahkan kini fenomena pakaian khas suku Dayak Bahau telah mendunia sehingga para masyarakat 
Dinamika Sosial Budaya, Vol 22, No. 1, Juni 2020, pp 29-37

p-ISSN: 1410-9859\& e-ISSN: 2580-8524

http://journals.usm.ac.id/index.php/jdsb

asing pun ikut memakai pakaian adat dengan ukiran khas suku Dayak Bahau ini (Hanafi, 2019). Kaitannya dengan komunikasi budaya tentu sangat terlihat dengan adanya berbagai temuan fakta bahwa sejak zaman dahulu pakaian digunakan sebagai media alat komunikasi budaya oleh masyarakat Dayak Bahau dan bahkan sebagai simbol kepercayaan mereka masing-masing. Sarwono (2012) Penggunaan motif batik klasik dalam busana di lingkungan masyarakat Surakarta ada maksud yang tersirat dan tersurat didalamnya ("Semiotika: Teori, Metode, dan Penerapannya," 2012). Yaitu penggunaan motif batik klasik dimaknai sebagai tanda status sosial, makna dan harapan suatu tujuan si pemakai, misalnya harapan kekuatan, kemenangan, kesejahteraan pada waktu itu. Inilah makna simbolisme yang tertuang dari berbagai jenis morif batik klasik dalam busana adat di Surakarta (Ulfia Krismawati, 2017). Penelitian ini dilakukan berdasarkan preferensi pendekatan semiotika-simbolisme busana adat permpuan di Pulau Buru. Penelitian ini untuk untuk melihat adanya suatu pola pemikiran masyarakat di Pulau Buru yang mendukungnya melalui tandatanda simbolisme dari bermacam motif maupun bentuk, sehingga tanda tersebut merupakan suatu bentuk konstruksi yang berhasil dibangun oleh masyarakat adat di Pulau Buru.

\section{METODE}

Paradigma yang dilakukan dalam penelitian ini adalah metode penelitian kualitatif, dimana analisis semiotika bertujuan untuk menemukan makna tanda termasuk hal-hal yang tersembunyi di balik sebuah tanda (Syafwandi \& Zubaidah, 2018). Dalam penelitian ini, semiotika digunakan sebagai alat analisis untuk mengungkap makna yang ada dibalik sebuah busana adat perempuan. Objek dalam penelitian ini adalah motif-motif kain serta model busana baju adat yang menjadi dipakai oleh peempuan di Pulau Buru. Teknik pengumpulan data dalam penelitian ini dilakukan dengan cara observasi, wawancara mendalam (depth interview), dan dokumentasi.

Observasi dilakukan untuk melengkapi format pengamatan sebagai instrumen untuk menggali lebih dalam mengenai motif-motif kain serta model busana baju adat yang dipergunakan. Depth interview dilakukan untuk mendapatkan informasi dari pengrajin dan tokoh masyarakat terkait motif kain, model busana baju adat dan maknanya. Penentuan informan dilakukan dilakukan dengan teknik purposive sampling yaitu peneliti yang menentukan sendiri informan yang akan diwawancarai berdasarkan pertimbangan representative (Vera, 2014).

Kriteria yang telah ditentukan dalam penelitian ini adalah Pengrajin yang memahami makna motif dan tokoh masyarakat yang mengetahui filosofi baju adat perempuan Teknik analisis data yang dilakukan dalam penelitian ini adalah analisis semiotika model teori segitiga makna atau "Triangle Meaning" Charles Sanders Pierce. Semiotik berobjekan tanda dan menganalisisnya menjadi ide, objek, dan makna. Ide dapat dikatakan sebagai lambang, sedangkan makna adalah beban yang terdapat dalam lambang yang mengacu pada objek tertentu[4]. Semiotika berangkat dari tiga elemen utama dari teori segitiga makna, yaitu (1) tanda adalah sesuatu yang dikaitkan pada seseorang untuk sesuatu dalam beberapa hal atau kapasitas (Wibowo, 2013). Tanda, adalah sesuatu yang berbentuk fisik yang dapat ditangkap oleh panca indera manusia dan merupakan sesuatu yang merujuk (merepresentasikan) hal lain di luar tanda itu sendiri; (2) objek adalah konteks sosial yang 
Dinamika Sosial Budaya, Vol 22, No. 1, Juni 2020, pp 29-37

p-ISSN: 1410-9859\& e-ISSN: 2580-8524

http://journals.usm.ac.id/index.php/jdsb

menjadi referensi dari tanda atau sesuatu yang dirujuk tanda; (3) Interpretant adalah konsep pemikiran dari orang yang menggunkan tanda dan menurunkannya ke suatu makna tertentu atau makna yang ada dalam benak seseorang tentang objek yang dirujukan sebuah tanda (Patricia, 2018). Yang dikupas dalam teori segitiga, adalah persoalan bagaimana makna muncul dari sebuah tanda ketika tanda itu digunakan orang pada waktu berkomunikasi.

\section{HASIL DAN PEMBAHASAN}

Kata busana secara harfiah diartikan pakaian yang lengkap (yang indah-indah) dan mulia, busana yang tidak perlu mewah. Bila dilihat dari aspek, antara lain aspek estetika (keindahannya) (Setyadi et al., 2018), dan juga aspek estetika langsung maupun tidak langsung berfungsi untuk memperindah dan menambah kesan mulia pada busana yang dikenakan oleh seseorang tentu di dalamnya juga terkait nilai-nilai filosofis dan simbolik (Afwadzi, 2015) seperti yang ditemukan pada beberapa desa adat di pulau Buru.

\subsection{Busana Adat Masyarakat Kayeli}

Perkembangan pakaian adat yang dikembangkan oleh manusia bukan hanya didorong oleh pemenuhan kebutuhan biologis untuk melindungi tubuh, tetapi juga didorong oleh kebutuhan budaya. Dalam masyarakat desa Kayeli, pengembangan pakaian adat dimulai dengan kehadiran tradisi berkumpul orang untuk mendengarkan nasihat dan petunjuk dari seorang pemimpin. Untuk pertama kalinya masyarakat berkumpul dengan kondisi pakaian kerja, untuk pria dengan tubuh telanjang atau sarung tangan depan terbuka saat perempuan membungkus kebaya. Perkembangan selanjutnya, terjadi perubahan dalam gaun di mana pertemuan masyarakat juga hadir para tamu dan undangan dari luar masyarakat desa Kayeli sehingga perlu untuk menghargai keberadaan mereka. Kaum pria diisyaratkan dengan memakai penutup badan dalam bentuk baju langsung berlengan pendek maupun panjang sementara perempuan diwajibkan untuk menggunakan selendang atau kain halus untuk menutupi bagian kepala.

Pada tahun 1800-1900 Kayeli adalah pusat Pemerintah dan kegiatan masyarakat bawah kekuasaan Kayeli, di mana raja sering memiliki petuanan (daerah kekuasaan), tetua adat dan tokoh agama untuk memiliki pengaruh pada perkembangan pakaian adat masyarakat Kayeli. Penciptaan pakaian adat pada masyarakat Kayeli dipercayai merupakan ritual yag dilakukan oleh orang adat pada generasi sebelumnya dan diwariskan secara turun temurun sehingga pakaian adat yang diwajibkan dianggap memiliki kesakralan. Menurut informan (HH) baju adat yang mereka miliki merupakan hasil jahitan sendiri, mereka tidak diperbolehkan untuk membeli di toko ataupun memakai bekas orang lain (diperbolehkan untuk keluarga atau pewaris). Kebaya maupun baju panjang dengan jahitan sederhana menjadi kebanggan bagi masingmasing orang ketika mereka menggunakannya dalam ritual-ritual adat.

Penggunaan pakaian tradisional di desa Kayeli umumnya digunakan ketika kondisi dan waktu tertentu saat upacara adat, ritual, hari besar, seperti pernikahan, khitanan, dan doa bersama. Hal ini menggambarkan bahwa identitas pengguna hanya di butuhkan dalam acara-acara tertentu. Status pengguna pakaian Adat adalah masyarakat setempat atau anak cucu keturunan yang berkaitan langsung dengan desa Kayeli. Dalam beberapa situasi, status pengguna juga bervariasi seperti pendatang maupun tamu undangan yang dibedakan dengan corak dan warna. Umumnya orang luar hanya menggunakan pakaian muslim dan penutup 
Dinamika Sosial Budaya, Vol 22, No. 1, Juni 2020, pp 29-37

p-ISSN: 1410-9859\& e-ISSN: 2580-8524

http://journals.usm.ac.id/index.php/jdsb

kepala berupa kerudung dan kopiah. Bagi masyarakat desa Kayeli, pakaian adat merupakan identitas yang merupakan kode etik yang harus dipatuhi sekalipun pengguna pakaian adat memiliki status social yang tinggi dalam urusan social ekonomi maupun struktur pemerintahan.

Secara umum warna putih merupakan unsur dominan dalam busana adat, keindahan terbentuk ketika unsur pakaian adat diseragamkan pada penutup kepala (kain batik) maupun penutup kepala bagi perempuan (selendang). Estetika itu terbentuk dengan adanya larangan menggunakan alas kaki selama pelaksanaan ritual seperti tari-tarian dan perjalanan adat lainnya (Tinarbuko, 2017). Larangan memakai alas kaki sebagai tanda bahwa masyarakat adat di desa Kayeli menyatu dengan bumi melalui pijakan langsung antara kaki dengan tanah. Menurut (RH) Struktur warna dan pola yang telah diatur dalam waktu sebelumnya menjadi pegangan bersama pada anak dan ahli waris dan tidak mudah untuk mengubah atau berubah sesuai dengan selera masing-masing orang. Larangan dalam penggunaan pakaian adat diatur seperti ketika seseorang melakukan hajat yang dianggap kotor seperti membuang air besar, membunuh, mencuri dan sejenisnya.

\subsection{Busana Adat Masyarakat Kubalahin}

Pakaian tradisional masyarakat Kubalahin pada umumnya hampir sama dengan pakaian di desa-desa yang tersebar di Kabupaten Buru ini menunjukkan bahwa masyarakat Buru pada umumnya memiliki budaya yang sama antara satu dengan lainnya (Rozi, 2013). Adapun perbedaan dari pakaian tradisional antara desa dan desa lainnya adalah campuran dari budaya yang bertransmigrasi ke pulau Buru seperti orangorang Sula, Bugis, Buton dan Jawa.
Masyarakat Kubalahin dalam upacara ritual wajib mengenakan pakaian tradisional yang diwariskan dalam bentuk pakaian keturunan yang berbentuk kebaya untuk wanita. Jenis pakaian sebelumnya dikenakan oleh wanita dari kalangan keluarga raja, guru, dan pemuka agama dan adat. Selain itu, assesoris berupa kancing berwarna juga ditambahkan ke tangan kebaya dan kancing berupa pin emas disertai dengan Cole atau kemeja batik dengan panjang lengan yang diberikan renda di bagian atas.

Cole ini terbuat dari kain putih dengan kancing pada dekorasi depan dan belakang bordir. Selain itu, penggunaan kaus kaki putih dan cenela dihiasi dengan motif bunga berwarna emas sebagai alas kaki dan berbentuk bulan di kepala diperkuat dengan tusuk sate Konde disebut Karkupeng. Adapun pria menggunakan pakaian pakaian cele, busana ini bermotif dengan garis-garis geometris yang umumnya dipakai pada upacara pelantikan raja, upacara cuci desa, serta acara panas pela.

Simbol yang melekat pakaian masyarakat adat Kubalahin menurut $(\mathrm{NN})$ adalah strata satu yang diatur oleh komposisi pakaian seperti motif dan warna. Warna merah adalah petunjuk bagi mereka yang dalam status menengah dan warna kuning dan pola bagi mereka yang tinggi status sosial. Larangan dan pembatasan diberikan kegiatan mengenai yang bisa membahayakan atau merusak hubungan kekerabatan seperti berkelahi, mencuri, mabuk-mabukan, membunuh. Dengan keterbatasan tersebut diharapkan pakaian adat yang digunakan untuk menjadi alat untuk menciptakan kondisi masyarakat yang sejahtera.

\subsection{Busana Adat Masyarakat Wasi}

Secara umum, pakaian tradisional masyarakat desa Wasi adalah Kebaya Manampal yang merupakan kebaya dari 
Dinamika Sosial Budaya, Vol 22, No. 1, Juni 2020, pp 29-37

p-ISSN: 1410-9859\& e-ISSN: 2580-8524

http://journals.usm.ac.id/index.php/jdsb

lengan ke siku yang dijahit oleh sepetak beberapa potong kain diatur dan disusun sedemikian rupa. Para wanita dari orangorang biasa di Desa Wasi menggunakan kebaya yang terbuat dari katun putih. Jenis Kebaya biasanya dipasangkan dengan kain palekat yang belum dipakai untuk bepergian dengan wanita. Bagi wanita, masyarakat Wasi adalah beberapa hal lain yang melengkapi pakaian tradisional ini. Yang pertama adalah konde. Konde yang digunakan adalah mirip konde untuk konde di Jawa pada umumnya, hanya ada beberapa perbedaan dalam aksesoris pendukung konde. Konde dibuat atau menyerupai emas dan perak disebut Haspel. Aksesoris ini juga dipasangkan dengan kaki telinga 4 buah dan berbentuk seperti bunga dan tidak lupa sisir konde ditempatkan di tengah-tengah konde itu. Aksesori lainnya adalah bunga Ron yang dilingkarkan di konde dan biasanya terbuat dari gabus.

Pada tahun 1900 Wasi berkembang dan menjadi dataran tinggi yang didiami oleh manusia, Wasi adalah salah satu daerah pegunungan di mana itu adalah jalan yang penting untuk mencapai danau rana. Untuk pembuatan pakaian adat di masyarakat Wasi dilakukan dalam keturunan dan diwariskan ke beberapa yang dipegang oleh tetua adat sebagai orang-orang yang memahami keberadaan pakaian tradisional, pakaian adat bagi masyarakat Wasi tidak diizinkan membeli yang telah jadi seperti yang tersedia pada gerai toko pakaian. Penggunaan pakaian tradisional di desa Wasi umumnya digunakan ketika kondisi dan waktu tertentu saat upacara adat, ritual, hari besar, seperti pernikahan, khitanan, dan lain-lain. Hal ini menggambarkan bahwa identitas pengguna hanya di butuhkan dalam acara-acara tertentu. Menurut (KN) pakaian adat tidak hanya diartikan sebagai pelindung atau hanya identitas masyarakat Wasi saja, tetapi memiliki beberapa fungsi dan persyaratan yang harus dipatuhi. Identitas pengguna yang merupakan anak cucu dari desa Wasi harus memperhatikan ikatan kepala, ulu parang (pegangan pedang), konde serta warna busana karena terdapat kode etik serta ketentuan yang sudah ditetapkan yang mampu memisahkan status penggunanya antara masyarakat desa Wasi maupun tamu yang diundang.

\subsection{Pemaknaan Terhadap Busana Adat}

Pakaian secara umum bagi orang di pulau Buru merupakan pelindung tubuh serta penunjuk identitas yang dipakai sehari-hari maupun pada kondisi tertentu. Masyarakat desa Kubalahin memposisikan pakaian adat sebagai suatu kewajiban yang harus ditaati oleh masyarakatnya. Kancing berwarna yang disematkan pada lengan baju menjadi identitas akan status seseorang yang memakainya. Lengan baju menjadi alasan ketika seseorang berkomunikasi dengan orang lain serta lengan baju tidak dapat disembunyikan yang menandakan bahwa status sosial seseorang harus bisa dilihat oleh orang lain. Begitu juga pin emas yang menandakan bahwa seseorang tersebut merupakan ahli waris dari keturunan yang berstatus sosial tinggi[10]. Pin berbentuk bulat dan terbuat dari emas menandakan kesejahteraan yang dimiliki dari orang yang memakainya, sehingga masyarakat diwajibkan menghargai mereka yang menggunakannya.

Pada bagian lain, pemakaian cole yang terkesan indah dan menawan dianggap mempertegas keberdaan seseorang yang disayang dan dipuja sehingga pengguna harus menggunakan kaus kaki sebagai pelindung kaki agar supaya terhindar dari kotoran serta melambangkan kesucian dari seseorang. Tusuk konde yang disebut karkupeng menjadi simbol seseorang 
Dinamika Sosial Budaya, Vol 22, No. 1, Juni 2020, pp 29-37

p-ISSN: 1410-9859\& e-ISSN: 2580-8524

http://journals.usm.ac.id/index.php/jdsb

memiliki kesejahteraan yang diukur dengan motif dan bahan karkupeng itu sendiri.

Makna Simbolis yang terdapat pada setiap bagian perhiasan dan maupun bahan yang pada intinya menjunjung tinggi nilainilai budaya pada masyarakat di desa Kubalahin. seperti nilai nilai kekerabatan,nilai sistem sosial, nilai kekeluargaan yang terdapat pada kain warna kain yang berwarna putih. Nilai kesopanan yang terdapat pada alas kaki dan penutup kepala serta nilai kemakmuran adalah yang ditunjukan dengan emas yang dipergunakan sebagai pin maupun kancing baju serta tusuk konde.

Masyarakat Kayeli dikenal dengan struktur masyarakat adat yang sangat kuat pengaruh dari ajaran islam. Pakaian adat yang dipergunakan merupakan toleransi yang lahir akibat ajaran yang dipercayai untuk membangun masyarakat yang sejahtera. Kebaya dan baju panjang memiliki makna kesetaraan serta kesejahteraan yang harus dimiliki oleh setiap orang di desa Kayeli sehingga sangat dilarang untuk membeli pakaian yang sudah jadi untuk dipergunakan sebagai busana adat. Warna putih yang diwajibkan pada busana adat melambangkan kesucian yang harus dihormati sehingga dengan pakaian adat yang berwarna putih seseorang dilarang untuk berbuat tindakan atau perbuatan yang dianggap mengotori kesucian dari baju adat tersebut.

Tutup kepala berupa selendang menandakan kearifan orang Kayeli dalam kesehariannya, begitu pula ikat kepala buat laki-laki yang bercorak batik merupakan gambaran tugas yang diemban oleh si pemakai. Salah satu simbol yang ditunjukan dengan ikat kepala adalah tanggung jawab laki-laki tersebut terhadap keluarga dan selendang yang dipergunakan merupakan alat untuk perempuan menjaga kehormatan keluarganya. Makna yang timbul dengan ikat kepala lebih dominan untuk tanggung jawab dan kehormatan (Pratiknjo, 2017).

Kaki telanjang mengindikasikan kedekatan manusia dengan alam, pemaknaan manusia yang terbuat dari tanah menyimpulkan masyarakat di desa Kayeli bahwa setiap manusia diwajibkan menyatu dengan tanah tanpa memandang status sosial maka kandungan nilai yang dimiliki dalam tindakan kaki telanjang adalah kesetaraan yang harus dijunjung sebagai nilai bersama bagi masyarakat desa Kayeli.

Masyarakat Wasi yang berada pada dataran tinggi merupakan bentuk masyarakat desa yang masih mempertahankan pola tradisi serta kebiasaan yang telah ada dari orang-orang sebelum mereka. Salah satunya busana adat kebaya manampal yang merupakan kebaya dari lengan ke siku yang dijahit oleh dari beberapa potong kain diatur dan disusun sedemikian rupa. Makna kebaya bukan sekedar bahan mempercantik seseorang namun lebih dari itu memiliki nilai tradisi serta nilai-nilai kemanusiaan yang harus dijunjung tinggi. Menampal artinya kain yang disambung dari kain sebelumnya hingga membentuk kebaya. Makna yang tersirat dalam menampal adalah tolong menolong dan bekerjasama dalam suatu pekerjaan. Sementara itu, untuk panjang kebaya sampai di siku menandakan bahwa perempuan di desa Wasi merupakan pengabdi bagi keluarganya. Pakaian yang panjangnya sampai di siku menandakan perempuan di desa Wasi siap bekerja sekalipun saat menggunakan pakaian kebaya yang dianggap simbol kemewahan atau tanda bahwa seseorang berada pada strata sosial yang tinggi.

Haspel menunjukan identitas masyarakat yang merujuk pada alam dimana empat kaki menunjukan arah mata angin (Yuliyanti et al., 2017). Simbol yang melekat bagi orang yang menggunakannya bahwa 
Dinamika Sosial Budaya, Vol 22, No. 1, Juni 2020, pp 29-37

p-ISSN: 1410-9859\& e-ISSN: 2580-8524

http://journals.usm.ac.id/index.php/jdsb

perempuan di desa Wasi siap mempertahankan rumah tangga jika kemanapun suami mereka pergi sekaligus menjadi penanggung jawab keluarga. Selain itu, sisir konde menandakan bahwa perempuan di desa Wasi akan merawat rumah tangganya dengan tetap bersolek untuk suami mereka. Kearifan masyarakat Wasi ditunjukan dengan baju putih serta ikat kepala sebagaimana putih dianggap sebagai keterbukaan bagi siapa saja serta ikat kepala bercorak batik dan berwarna coklat yang memiliki simbol status sosial bagi penggunanya.

\section{KESIMPULAN}

Makna Simbolis yang terdapat pada setiap bagian baju adat memiliki makna dan arti tertentu. Warna, bentuk, hiasan serta petunjuk menjadikan baju adat sebagai suatu tata nilai yang memiliki nilai paksa terhadap penggunanya. Simbol dan tanda yang melekat memiliki arti untk menjunjung tinggi nilai kekerabatan, kebersamaan, kesopanan serta tanggung jawab sehingga setiap orang yang menggunakan baju adat harus mengikuti serta memahami makna yang terkandung di dalamnya.

Persamaan nilai yang dimiliki oleh baju adat dari ketiga desa tersebut adalah sebagai penunjuk identitas dalam strata sosial dimana seseorang dengan jelas dapat dikatahui dengan pakaian adat yang digunakan. Baju adat juga melahirkan nilai kesetaraan melalui warna putih yang dianggap mampu diterima oleh pihak manapun. Selain itu nilai gotong royong dan kerjasama di tandai dengan menjahit baju adat yang dilakukan oleh masyarakat pada ketiga desa tersebut.

\section{DAFTAR PUSTAKA}

Afwadzi, B. (2015). Teori Semiotika Komunikasi Hadis ala Umberto Eco. MUTAWATIR.

https://doi.org/10.15642/mutawatir.201 4.4.2.179-210

Eirumkuy Balai Pelestarian Nilai Budaya Ambon Jln IrMPutuhena Wailela Rumahtiga Ambon, E. (2013). Suku Bangsa Di Kabupaten Buru the Tribe in Buru Regency. Jurnal Penelitian.

Hanafi, W. (2019). HIPERSEMIOTIKA (Kritik Nalar Semiotika sebagai Teori Dusta dalam Reinterpretasi Qur'anic Studies). $Q O F$. https://doi.org/10.30762/qof.v3i1.1029

Kodariah dan Gugun Gunardi, S. (2015). NILAI KEARIFAN LOKAL DALAM PERIBAHASA SUNDA: KAJIAN SEMIOTIKA. Patanjala: Jurnal Penelitian Sejarah Dan Budaya. https://doi.org/10.30959/patanjala.v7i1. 88

Nugrahenny, T. T. (2018). Menyingkap Mekanisme Tanda di Balik Hiperrealitas Tren Hijab (Analisis Semiotika pada Fenomena Tren Hijab). Jurnal Komunikasi Indonesia. https://doi.org/10.7454/jki.v5i1.8317

Patricia, F. D. (2018). Analisis Semiotika Komunikasi Visual Buku "Memahami Komik" Scott McCloud. Jurnal Studi Komunikasi (Indonesian Journal of Communications Studies). https://doi.org/10.25139/jsk.v2i2.702

Pratiknjo, M. H. (2017). Identitas Dan Bentuk-Bentuk Budaya Lokal Masyarakat Kabupaten Kepulauan Talaud Di Daerah Perbatasan IndonesiaFilipina. Antropologi Indonesia. https://doi.org/10.7454/ai.v37i1.8764

Rozi, S. (2013). Konstruksi Identitas Agama Dan Budaya Etnis Minangkabau Di Daerah Perbatasan: Perubahan Identitas Dalam Interaksi Antaretnis Di Rao Kabupaten Pasaman Sumatera Barat. In Jurnal Masyarakat Indonesia.

Semiotika: Teori, Metode, dan Penerapannya. (2012). Humaniora. https://doi.org/10.22146/jh.v10i1.607

Setyadi, M. A., Putri, Y. R., \& Putra, A. (2018). Analisis Semiotika Ferdinand 
Dinamika Sosial Budaya, Vol 22, No. 1, Juni 2020, pp 29-37

p-ISSN: 1410-9859\& e-ISSN: 2580-8524

http://journals.usm.ac.id/index.php/jdsb

De Saussure Sebagai Representasi Nilai Kemanusiaan dalam Film the Call Analysis of Ferdinand. E-Proceeding of Management.

Syafwandi, \& Zubaidah. (2018). MAKNA FILOSOFI ORNAMEN HIAS TRADISIONAL MINANGKABAU MASIHKAH RELEFAN DENGAN POLA KEHIDUPAN MASYARAKAT SEKARANG. Ranah Seni. https://doi.org/10.24036/ranahseni.v12i 01.36

Tinarbuko, S. (2017). Semiotika Tanda Verbal dan Tanda Visual Iklan Layanan Masyarakat. Panggung. https://doi.org/10.26742/panggung.v26i 2.175

Ulfia Krismawati, N. (2017). Batik Pring: Sejarah Perkembangan Batik Modern
Desa Sidomukti Tahun 2002-2015

Kecamatan Plaosan Kabupaten

Magetan. AGASTYA: JURNAL SEJARAH DAN PEMBELAJARANNYA. https://doi.org/10.25273/ajsp.v7i2.1488

Vera, N. (2014). Semiotika dalam riset komunikasi. In Ghalia Indonesia.

Wibowo, I. S. W. (2013). Semiotika komunikasi Aplikasi Praktis Penelitian dan Skripsi Komunikasi. In ウイルス.

Yuliyanti, F. D., Bajari, A., \& Mulyana, S. (2017). Representasi Maskulinitas Dalam Iklan Televisi Pond's Men \#Lelakimasakini (Analisis Semiotika Roland Barthes Terhadap Representasi Maskulinitas). Jurnal Komunikasi. https://doi.org/10.24912/jk.v9i1.180 